\title{
Distribution of Agrin mRNAs in the Chick Embryo Nervous System
}

\author{
Enbo Ma, Rodney Morgan, and Earl W. Godfrey \\ Department of Cellular Biology and Anatomy, Medical College of Wisconsin, Milwaukee, Wisconsin 53226
}

\begin{abstract}
Agrin is a synapse-organizing protein likely to mediate nerveinduced aggregation of acetylcholine receptors and other postsynaptic components at the neuromuscular junction. We used in situ hybridization and polymerase chain reaction (PCR) to define the localization of agrin mRNA and its alternatively spliced forms in the chick embryo nervous system. Agrin cRNA probes intensely labeled motor neurons, dorsal root ganglia, cerebellar Purkinje neurons, and retinal ganglion cells. Neuronal layers in optic tectum and ventricular regions were also labeled. Analysis by PCR showed that all parts of the nervous system at embryonic day 10 contained three major forms of agrin mRNA. Our results raise the possibility that agrin isoforms play a role in synapse formation or other aspects of neuronal development in the central nervous system.
\end{abstract}

IKey words: agrin, synapse formation, extracellular matrix, chick embryo, polymerase chain reaction, in situ hybridization]

Agrin is the first synapse-organizing protein to be identified. Evidence is growing that agrin is the molecule provided by the motor axon that induces the formation of the postsynaptic apparatus at both the developing and the regenerating neuromuscular junction. Agrin is synthesized in motor neurons, is transported down their axons, and becomes associated with the synaptic basal lamina at the neuromuscular junction (Reist et al., 1987; Magill-Solc and McMahan, 1988, 1990). Originally isolated from extracellular matrix (ECM) of the synapse-rich Torpedo electric organ (Godfrey et al., 1984, 1988a; Nitkin et al., 1987), agrin causes the redistribution of acetylcholine receptors (AChRs) and other postsynaptic components into dense aggregates on the surface of skeletal muscle cells (Godfrey et al., 1984; Wallace, 1989). Recent studies of neuromuscular interaction show that agrin is likely to be involved in organizing postsynaptic structures from the time they first appear in development. First, anti-agrin antibodies block nerve-induced AChR aggregation on muscle cells (Reist et al, 1992). Second, microaggregates of AChRs at newly formed nerve-muscle contacts in culture are colocalized with microaggregates of neuronal

\footnotetext{
Received June 29, 1993; revised Oct. 14, 1993; accepted Nov. 1, 1993.

Chicken agrin cDNA clones were a generous gift of Drs. K. Tsim and U. J. McMahan (Stanford University). We thank Nancy Drzewiecki for expert technical assistancc and valuable discussion, Nadine Halligan and Dr. Peter Newman for valuable advice, Sue Tjepkema-Burrows and Deb Generotzky for excellent photographic assistance, and Drs. Maya Sieber-Blum and Gary Lyons for critically reading the manuscript. This work was supported by grants from the National Institutes of Health (NS27218 and HD 20743).

Correspondence should be addressed to Earl W. Godfrey, Ph.D., Department of Cellular Biology and Anatomy, Medical College of Wisconsin, 8701 Watertown Plank Road, Milwaukee, WI 53226.

Copyright (C) 1994 Society for Neuroscience $0270-6474 / 94 / 142943-10 \$ 05.00 / 0$
}

agrin-like molecules on the surface of the motor axon (Cohen and Godfrey, 1992). Thus, agrin appears to be involved in neuromuscular synaptogenesis from the time axons contact muscle cells.

In addition to agrin's localization in the synaptic basal lamina, agrin-like proteins are also present in most other basal laminae (Godfrey et al., 1988a,b; Godfrey, 1991). In the chicken, agrinlike proteins purified from non-neural tissues such as muscle, kidney, and heart have much less AChR-aggregating activity than agrin from brain or spinal cord (Godfrey, 1991). This difference in activity of agrin-like molecules from various tissues may be due to alternative splicing of agrin mRNA. Complete cDNA sequences coding for rat and chicken agrin have recently been obtained (Rupp et al., 1991; Tsim et al., 1992). In the chick embryo, several variants of agrin mRNA have been detected (see Fig. 6). These differ in sequence by the presence or absence of inserts at two positions near the $3^{\prime}$ end of the molecule, designated A (nucleotides 5016-5027) and B (5423-5455; Ruegg et al., 1992; Tsim et al., 1992). When partial cDNAs were expressed as soluble proteins in a transfected cell line, only cDNAs containing inserts at both positions $\Lambda$ and $B$ encoded protcins with AChR-aggregating activity (Ruegg et al., 1992). Variants that lack one or both inserts $\left(A_{0} B_{0}\right.$ and $\left.A_{1} B_{0}\right)$ encoded proteins with little or no AChR-aggregating activity in this assay, and were detected in both neural and non-neural tissues. The $A_{4} B_{11}$ variant, which encodes an isoform that may have greater AChRaggregating activity than those lacking the inserts (Ruegg et al., 1992; Ferns et al., 1993), was found only in the nervous system of the chick embryo (Ruegg et al., 1992). In a more recent study, $\mathrm{B}_{8}$ and $\mathrm{B}_{19}$ inserts were also detected in the chick ciliary ganglion (Thomas et al., 1993), bringing the total number of variants to four at the B position. Similar sequence variants have been found in the rat (Ferns et al., 1992; Hoch et al., 1993).

Having the sequence of agrin mRNA variants makes it possible to determine their distribution and pattern of expression. Agrin's AChR-aggregating activity is present in embryonic brain, especially in regions containing motor neurons (Magill-Solc and McMahan, 1988; Godfrey, 1991). However, the precise distribution of agrin in the developing nervous system has not been reported. We have used a combination of in situ hybridization histochemistry and polymerase chain reaction (PCR) to study the distribution of agrin mRNA and its alternatively spliced forms in the chick embryo nervous system. We found that agrin mRNAs are concentrated in only a few structures in the developing nervous system. All regions of the nervous system that were surveyed contained agrin mRNAs likely to encode proteins with potent $\mathrm{AChR}$-aggregating activity and also those encoding agrin isoforms that may have less activity. Our results raise the possibility that agrin isoforms may play a role in the development of connections between specific sets of neurons within the 


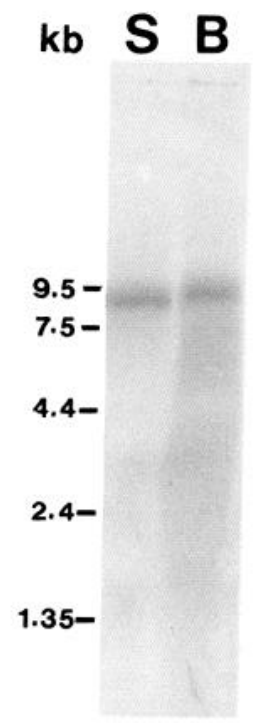

Figure 1. Northern hybridization of RNA from E14 chick embryo spinal cord $(S)$ and brain $(B)$ with an antisense cRNA probe for chicken agrin. RNA was purified as described in Materials and Methods; $3 \mu \mathrm{g}$ of polyA ${ }^{+}$RNA from spinal cord and $20 \mu \mathrm{g}$ of total RNA from brain were loaded on a formaldehyde-agarose gel. Following electrophoresis and transfer of RNA to nylon membrane, hybridization was performed using the same digoxigenin-labeled antisense cRNA probe for chicken agrin that was used for in situ hybridization. One transcript of $\sim 8.2 \mathrm{~kb}$ was detected. Numbers at left indicate migration of RNA size standards (kilobases).

CNS, in addition to their function at developing neuromuscular synapses.

Some of this work has been reported in abstract form (Ma and Godfrey, 1992).

\section{Materials and Methods}

Northern hybridization. Total RNA was prepared from chick embryo [day 14 (E14)] spinal cord and brain using RNAzol (Tel-Test, Inc.); polyA ${ }^{+}$RNA was purified with the Micro-FastTrack kit (Invitrogen). A formaldehyde-containing agarose $(1.2 \%)$ gel was loaded with $3 \mu \mathrm{g}$ per lane of polyA + RNA from spinal cord and $20 \mu \mathrm{g}$ of total RNA from brain. Following electrophoresis, RNA was transferred to nylon $(0.45$ $\mu \mathrm{m}$ pore size; Micron Separations, Inc., Westboro, MA). The blot was prehybridized $3 \mathrm{hr}$, probed $\left(45^{\circ} \mathrm{C}\right.$ overnight, $50 \%$ formamide) with a digoxigenin-labeled antisense cRNA probe specific for the $5^{\prime}$ end of chicken agrin mRNA (nucleotides 1-1145), and washed twice in $1 \times$ SSC, $0.1 \%$ SDS $30 \mathrm{~min}$ at room temperature, then twice $45 \mathrm{~min}$ in $0.1 \times$ SSC, $0.1 \%$ SDS at $70^{\circ} \mathrm{C}$. Probe was detected with anti-digoxigenin antibodies linked to alkaline phosphatase (Genius kit, Boehringer-Mannheim), according to the manufacturer's instructions. An RNA ladder (GIBCO-Bethesda Research Labs) was used as a size standard.

In situ hybridization. Chick embryos (White Leghorn eggs, Sunnyside, Beaver Dam, WI) were used at E2 [stage (St) 15], E3 (St 18), E4 (St 23), E5 (St 26), E6 (St 28), E7 (St 30), E9 (St 35), E10 (St 36), E14 (St 40), and E18 (St 44); 3-d-old chicks (P3) were also used. Embryos were staged by the criteria of Hamburger and Hamilton (1951). Chick brain and chick embryo heads were prefixed $3 \mathrm{hr}$ in $4 \%$ paraformaldehyde, embedded in OCT medium, and stored at $-80^{\circ} \mathrm{C}$. Chick embryo trunks were dissected, immediately embedded, and frozen without fixation.
Digoxigenin-labeled agrin cRNA probes were synthesized using the Genius kit according to the manufacturer's instructions (DIG RNA labeling kit, Boehringer-Mannheim). The templates were an 1100 base pair (bp) fragment at the 5 '-end of the chicken agrin cDNA (nucleotides 1-1145) and a 2800 bp fragment near the center of the cDNA (nucleotides 690-3460; Tsim et al., 1992). These agrin cDNA clones, in Bluescript KS with T3 and T7 promoters, were a gift of Drs. K. Tsim and U. J. McMahan (Stanford University). For hybridization of prefixed tissues, probes were hydrolyzed into fragments of $150-170 \mathrm{bp}$ in $80 \mathrm{~mm}$ $\mathrm{NaHCO}_{3}, 120 \mathrm{~mm} \mathrm{Na}_{2} \mathrm{CO}_{3}$, pH 10.2 (Angerer et al., 1987).

For in situ hybridization, $16 \mu \mathrm{m}$ cryostat sections were mounted on 3-aminopropyltriethoxysilane-coated slides, fixed $5 \mathrm{~min}(2 \mathrm{~min}$, prefixed tissues) in PBS with 4\% paraformaldehyde, rinsed twice in PBS, and dried. The fixed sections were incubated in prehybridization buffer [ $50 \%$ deionized formamide, $0.75 \mathrm{~m} \mathrm{NaCl}, 25 \mathrm{~mm}$ PIPES, $25 \mathrm{~mm}$ EDTA, $5 \times$ Denhardt's, $0.2 \%$ SDS, $10 \mathrm{~mm}$ dithiothreitol, $500 \mathrm{mg} / \mathrm{ml}$ denatured herring sperm DNA, $300 \mu \mathrm{g} / \mathrm{ml}$ polyA, and $300 \mu \mathrm{g} / \mathrm{ml}$ tRNA] for $3 \mathrm{hr}$ at $50^{\circ} \mathrm{C}$, covered with $70 \mu \mathrm{l}$ of cRNA probe $(0.57 \mathrm{ng} / \mu \mathrm{l})$ in hybridization buffer (prehybridization buffer plus $10 \%$ dextran sulfate), and incubated overnight at the same temperature. After hybridization, sections were rinsed twice in $4 \times \mathrm{SSC}$, treated with $60 \mu \mathrm{g} / \mathrm{ml} \mathrm{RNase} \mathrm{A}\left(37^{\circ} \mathrm{C}, 30 \mathrm{~min}\right)$, and rinsed $30 \mathrm{~min}$ in the same buffer, once in $1 \times \mathrm{SSC}$ at room temperature, and once in $1 \times \mathrm{SSC}$ at $58^{\circ} \mathrm{C}$. After the last wash, sections were treated to reveal digoxigenin-labeled probes with alkaline phosphataseconjugated anti-digoxigenin antibody (1:1000 dilution) and substrates, according to the protocol provided by Boehringer-Mannheim. After mounting with Permount and coverslips, the sections were observed and photographed using a Nikon Optiphot microscope and camera. In control experiments, no specific labeling was observed in adjacent sections in each group hybridized with either sense cRNA probe or without a probe to check endogenous phosphatase activity.

Polymerase chain reaction. To obtain mRNA, all tissues were rapidly dissected on ice from E10 (St 36) embryos, except for heart (St 28) and limb (St 23). The mRNA was isolated with the Micro-FastTrack mRNA Isolation Kit (Invitrogen) and first-strand cDNA was synthesized with M-MLV reverse transcriptase and specifically primed using the primer $\mathrm{B}_{\mathrm{a}}$ (see below).

To identify agrin mRNA variants, we tested for the presence of inserts at positions A (nucleotide 5016) and B (nucleotide 5423; Tsim et al., 1992). Polymerase chain reaction was used to amplify region $A$ with primers $A_{s}$ and $A_{a}$, and region $B$ with primers $B_{s}$ and $B_{a}$. The sequence and position of these primers were, for $A_{s}, 5$ 'CAACACCTGGATAAGCG-3' (nucleotides 4926-4942); A , 5'-ATGGCTCCTTCAGGTTGAGG-3' (5043-5062); Bs, 5'-TTTGATGGTAGGACGTACAT-3' (5377-5396); and B $\mathrm{B}_{a}, 5^{\prime}$-TCTGTTTTGATGCTCAGCTC-3' (5485-5504; see Fig. 8). The PCR reaction mixture $(100 \mu \mathrm{l})$ contained $1 \mu \mathrm{l}$ of the cDNA mixture, $10 \mathrm{~mm}$ Tris $\mathrm{HCl}(\mathrm{pH} 8.3), 50 \mathrm{~mm} \mathrm{KCl}, 2.5$ $\mathrm{mm} \mathrm{MgCl}_{2}, 0.1 \mathrm{~mm}$ dATP, $0.2 \mathrm{~mm}$ each of the other nucleotides, 25 pmol of each primer, $1 \mu \mathrm{l}$ of ${ }^{35} \mathrm{~S}$-dATP $(1000 \mathrm{Ci} / \mathrm{mmol}$; Amersham), and $2.5 \mathrm{U}$ of Taq DNA polymerase (Promega), which was added to the other components after heating to $95^{\circ} \mathrm{C}$. Amplification was performed in a PTC-100 thermal cycler (MJ Research, Inc.) using 35 cycles of $95^{\circ} \mathrm{C}$ for $1 \mathrm{~min}, 55^{\circ} \mathrm{C}$ for $1 \mathrm{~min}$, and $72^{\circ} \mathrm{C}$ for $1 \mathrm{~min}$, followed by a 7 min extension at $72^{\circ} \mathrm{C}$. Five microliters of each reaction was analyzed on an $8 \%$ polyacrylamide sequencing gel in TBE buffer (Sambrook et al., 1989). The gel was dried and autoradiography was performed $42-$ $96 \mathrm{hr}$.

$D N A$ sequencing of $P C R$ products. To confirm that the PCR products were amplified from agrin variants, direct sequencing of the products from position $\mathrm{B}$ was performed. Products from PCR with primers $\mathrm{B}_{2}$ and $\mathrm{B}_{5}$ were separated by electrophoresis in a $3 \%$ SeaPlaque (FMC BioProducts) agarose gel. Individual bands were cut out and purified with the Mermaid Kit (Bio 101); sequencing was performed with the fmol DNA Sequencing System (Promega), as specified by the manufacturer. The amplification primers, $5^{\prime}$ end labeled with T4 polynucleotide kinase and $\gamma$ - $^{32} \mathrm{P}-\mathrm{dATP}(10 \mathrm{mCi} / \mathrm{ml}, 3000 \mathrm{Ci} / \mathrm{mmol})$, were used for direct sequencing.

Figure 2. Distribution of agrin mRNAs in the lumbar spinal cord of the developing chick embryo. $A$, E3 (St 18); $B$, E4 (St 23); $C$, E5 (St 26); $D$, E10 (St 36); $E$, E14 (St 40); $F$, E18 (St 44) ( $A-F$ all hybridized with antisense agrin cRNA probe); $G$, enlargement of boxed region in $E$ (E14); $H$, sense cRNA control hybridized to section of E10 spinal cord. Arrows, presumptive motor neurons, where the agrin mRNA signal was consistently seen; arrowheads, ventricular region. $d$, dorsal root ganglion; $n$, notochord; $s$, somitic myotome. Scale bars: $A-C, 100 \mu \mathrm{m} ; D-F$ and $H, 200 \mu \mathrm{m}$; $G, 50 \mu \mathrm{m}$. 


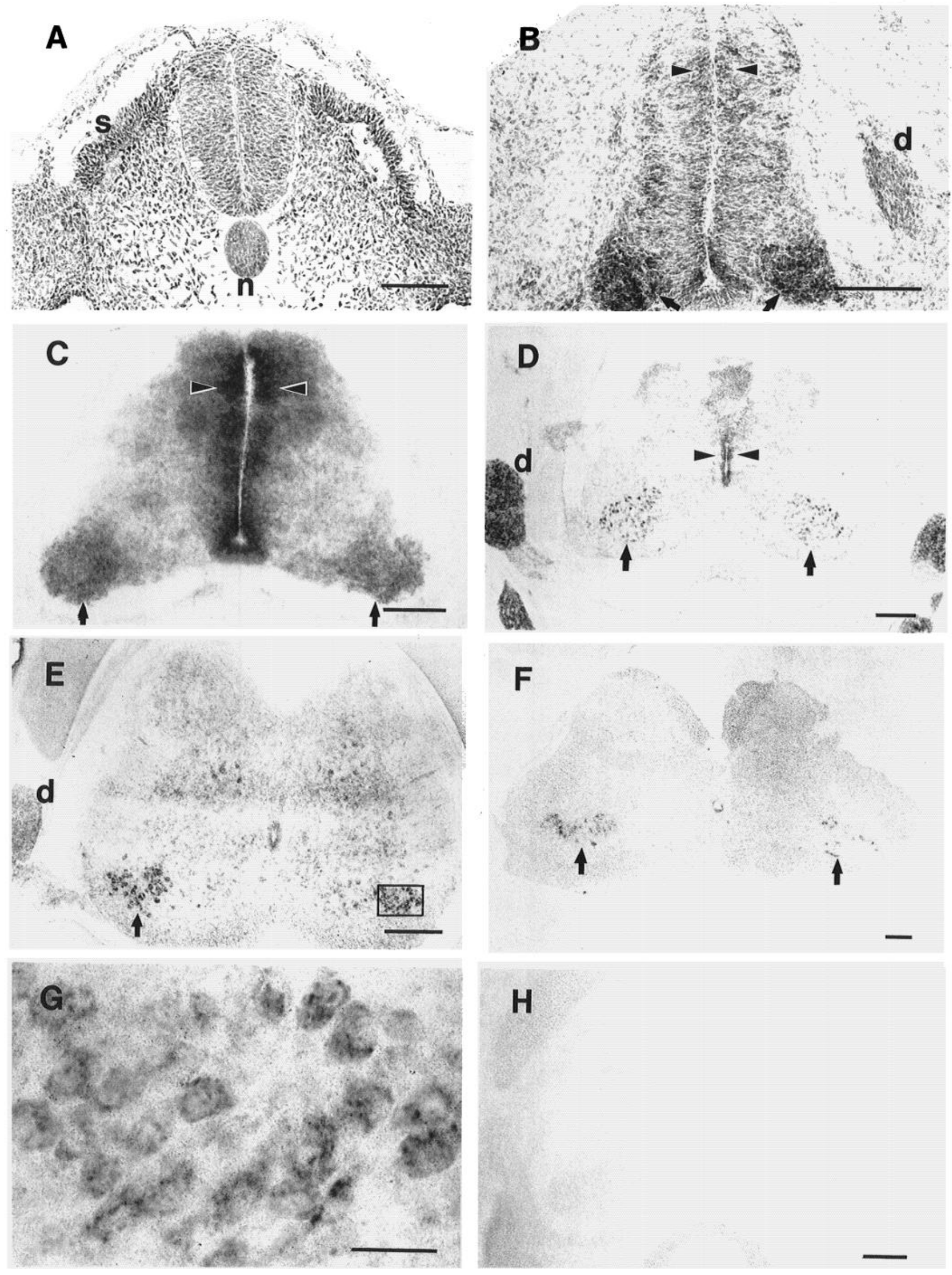



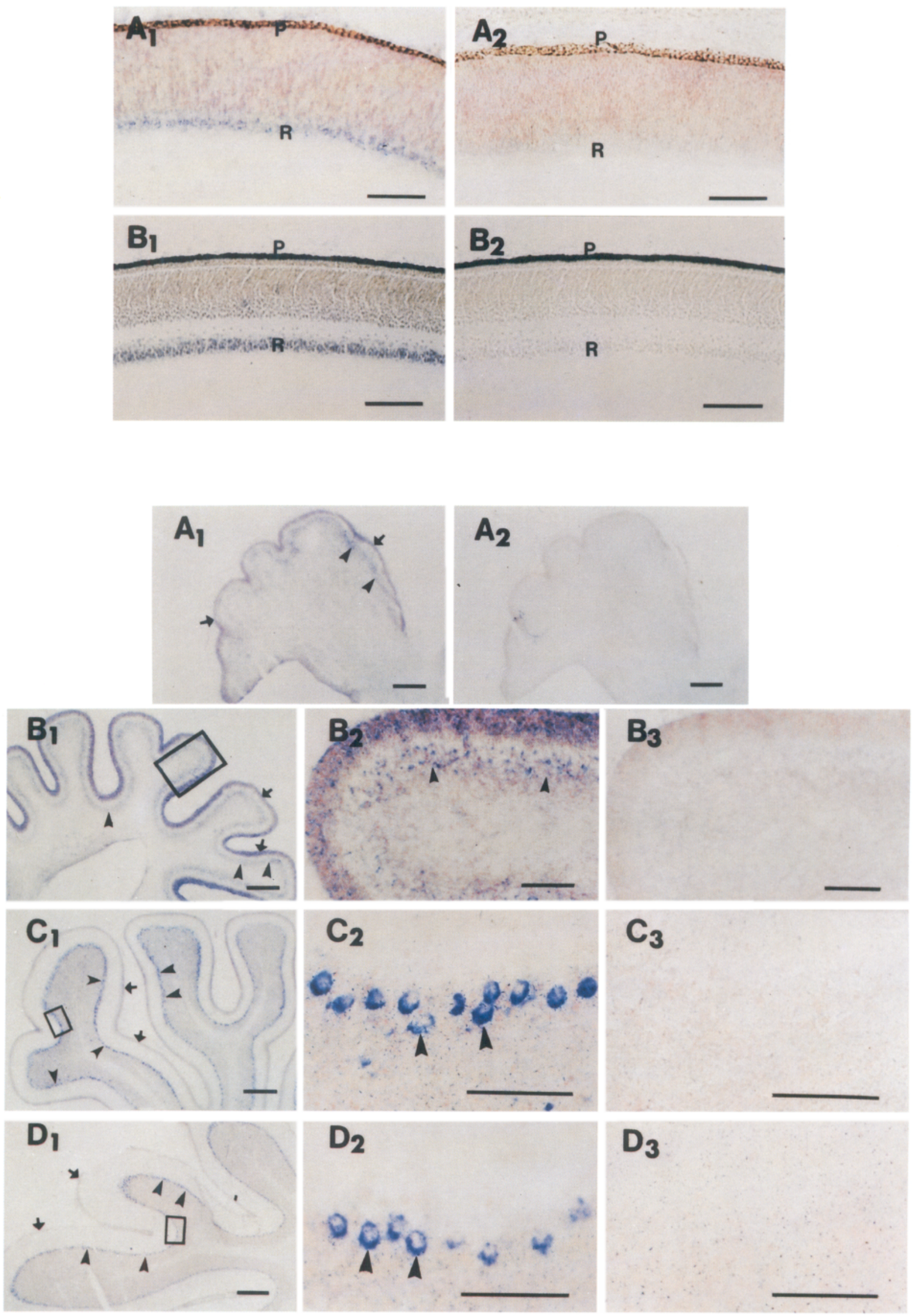


\section{Results}

Specificity of probes used for in situ hybridization

Two different antisense agrin riboprobes (cRNA probes) were synthesized from chicken agrin cDNA clones. One probe was complementary to the initial $\sim 1$ kilobase $(\mathrm{kb})$ at the $5^{\prime}$ end of the $\sim 8 \mathrm{~kb}$ agrin mRNA sequence; the other probe represented $\sim 3 \mathrm{~kb}$ in the center of the agrin mRNA. Most of the in situ hybridization data were derived from the $5^{\prime}$-most probe, but the other probe gave identical results (comparison not shown). The $5^{\prime}$-most probe hybridized with only one band of $\sim 8.2 \mathrm{~kb}$ in Northern blot analysis of mRNA from chick embryo spinal cord and brain (Fig. 1). In dot blotting experiments, antisense cRNA probe hybridized with mRNA isolated from E12 chick spinal cord, while the corresponding sense probe did not (not shown). In situ hybridization with the antisense probes showed that agrin mRNA was concentrated in portions of the embryo known to contain high levels of agrin protein, including ventral spinal cord (Fig. 2B) and embryonic kidney (not shown). The antisense cRNA signal was localized intracellularly (Figs. $2 G$; $4 C_{2}, D_{2}$, arrowheads), while sense cRNA probes did not yield specific hybridization patterns (e.g., Figs. $2 H, 3 B_{2}, 4 B_{3}, 5 A_{3}, B_{2}$ ). Furthermore, hybridization without probe showed no signal, indicating a lack of nonspecific antibody binding and endogenous phosphatase activity (not shown).

\section{Distribution of agrin $m R N A$ s in developing spinal cord and sensory ganglia}

The early (E2-E3) neural tube and surrounding tissues had a low but uniform level of agrin mRNA (E2, not shown; E3 = St 18; Fig. 2A). However, by E4 (St 23) the lumbar spinal cord contained a population of ventrolateral cells, presumably motor neurons, that were labeled intensely with agrin antisense probes (arrows, Fig. 2B). The signal in the presumptive motor neurons appeared to be at its greatest intensity at this early stage. Increased hybridization was also found in the area around the central canal of the spinal cord (arrowheads, Fig. $2 B$ ), and at this stage sensory ganglia also were labeled ("d," Fig. $2 B$ ). At E5-E6 (St 25-28), when the first neuromuscular synapses form in the limb, ventrolateral cells were still labeled (arrows, Fig. $2 C$ ), but in addition, intense labeling surrounded the central canal, especially dorsally, in the lumbar spinal cord (arrowheads, Fig. 2C). Interestingly, the hybridization signal in ventrolateral spinal cord at E5-E9 seemed much weaker in sections of thoracic spinal cord than in the lumbar region, suggesting that motor neurons innervating limb muscles contain a much higher level of agrin mRNA than those supplying axial musculature (not shown). At E10 (St 36), the putative motor neurons again contained the greatest signal (arrows, Fig. $2 D$ ), while the area around the central canal stained significantly less than at E5-6 (arrowheads, Fig. 2D). At E14 (St 40; Fig. 2E) and E18 (St 44; Fig. $2 F$ ), agrin mRNA was primarily concentrated in motor neurons, but the intensity of the signal appeared to decrease with development. The reaction product was localized in the cytoplasm of putative motor neurons (E14; Fig. $2 G$ ), as expected. Sensory ganglia from E5 to E14 were also prominently labeled (“d," Fig. $2 D, E)$. The largest sensory ganglion cells, presumably neurons, were most intensely labeled (not shown). Sections hybridized with sense cRNA probe showed no specific signal in the spinal cord at any stage (e.g., at E10; Fig. 2H).

\section{Agrin $m R N A$ s in developing retina}

Four stages (E6, St 28; E7, St 30; E9, St 35; E10, St 36) were selected for studying the distribution of agrin mRNAs in developing retina. Agrin $\mathrm{mRNAs}$ at the earlier stages were concentrated in the retinal ganglion cell layer (labeled "R," Fig. $3 A_{1}$, E7; E6 not shown). At E9 and E10, the retina was clearly differentiated, with several layers evident. Agrin mRNAs at these stages were still concentrated in the retinal ganglion cell layer (labeled "R," Fig. $3 B_{I}$ ), but some signal was also seen in all cellular layers between the ganglion cell layer and the pigmented epithelium. The sense cRNA probe control labeled the retina at these stages in a uniform pattern and much less intensely (Fig. $3 A_{2}, B_{2}$ ).

\section{Agrin $m R N A$ s in embryonic brain}

In the development of the cerebellum, a low level of reaction product was first observed at E9, when the cerebellar plate has first formed (not shown). At E10 some signal was clearly localized in the presumptive Purkinje cell layer (arrowheads, Fig. $4 A_{1}$ ). Compared with earlier stages, at E14 (St 40) the signal in the Purkinje cell layer was increased (arrowheads, Fig. $4 B_{1}, B_{2}$ ), although a lesser signal was also seen in the external granule cell layer (Fig. $4 B_{l}$, arrows; $B_{2}$ ). By E18 (St 44), agrin mRNA reached a maximal level and was clearly concentrated in Purkinje cells (arrowheads, Fig. $4 C_{1}, C_{2}$ ). At P3, the agrin mRNA signal was still seen in Purkinje cells (arrowheads, Fig. $4 D_{1}, D_{2}$ ), but was decreased when compared with that at E18. No specific signal was found with sense cRNA probe controls (Fig. $4 A_{2}, B_{3}, C_{3}, D_{3}$ ).

Much of the embryonic brain had a low and fairly uniform level of hybridization with agrin antisense cRNA probes, which was nevertheless greater than in controls with sense cRNA (Fig. $\left.5 A_{3}, B_{2}\right)$. However, several brain regions were prominently labeled with agrin probes. The E6 (St 28) telencephalon was intensely labeled, especially in the superior region (Fig. $5 A_{1} ; A_{2}$, arrowheads). By E9 or E10 the agrin mRNA signal in the telencephalon was greatly diminished, remaining primarily in the ventricular region (not shown). The agrin mRNAs in the optic tectum were mainly localized to the ventricular layer at E6 (not shown), but by E9 or E10, when axons of retinal ganglion neurons begin to form synapses on tectal neurons (Rager, 1976), several more peripheral layers, presumably neuronal, were also labeled (arrowheads, Fig. $5 B_{1}$ ). Cranial motor nuclei in the

Figure 3. Distribution of agrin mRNAs in developing retina. $A_{l}$ (E7; St 30) and $B_{l}$ (E9; St 35), Retina, showing agrin mRNA signal concentrated in ganglion cell layer $(R) . A_{2}(\mathrm{E} 7)$ and $B_{2}(\mathrm{E} 9)$, Sense cRNA probe controls for $A_{1}$ and $B_{1}$. Retinal ganglion cell layer $(R)$ is at the bottom and pigment epithelium $(P)$ at the top in all micrographs. Scale bars, $100 \mu \mathrm{m}$.

Figure 4. Distribution of agrin mRNAs in developing cerebellum, seen in sagittal sections. $A_{1}:$ E10 (St 36 ); $A_{2}$ : sense cRNA control for $A_{l} . B_{l}$, E14 (St 40); $B_{2}$, enlargement of boxed area in $B_{1} ; B_{3}$, sense cRNA control for $B_{2} . C_{1}$, E18; $C_{2}$, enlargement of boxed area in $C_{1}$; $C_{3}$, sense cRNA control for $C_{2}$. $D_{1}$, P3 (3 d posthatching); $D_{2}$, enlargement of boxed area in $D_{1} ; D_{3}$, sense cRNA control for $D_{2}$. Purkinje cells were heavily labeled, especially at E18 $(C)$ and P3 $(D)$ (arrowheads). Agrin mRNA signal was localized in cytoplasm of these cells (large arrowheads, $\left.C_{2}, D_{2}\right)$. Scale bars: $A_{l}, A_{2}, B_{l}, C_{l}, D_{l}, 300 \mu \mathrm{m} ; B_{2}, B_{3}, C_{2}, C_{3}, D_{2}, D_{3}, 100 \mu \mathrm{m}$. 
brainstem were heavily labeled, as expected, since they contain motor neurons (asterisks, Fig. 5C). In the diencephalon, signal was also found in the habenular nucleus (arrow, Fig. $5 D$; E9).

\section{Analysis of agrin $M R N A s$ with PCR}

The structure of the agrin cDNA and the position of inserts encoding variant sequences is shown in Figure 6. To determine the tissue distribution of the alternatively spliced mRNA variants and confirm the results of in situ hybridization, PCR was used to amplify independently the two regions of cDNAs synthesized from embryonic mRNAs of E4-E10 non-neural (limb, muscle, kidney, and heart) and E10 neural tissues (spinal cord, dorsal root ganglion, retina, and parts of brain). The DNA bands shown in Figure 7 were observed in five independent amplifications from two different sets of cDNA preparations. No bands were observed when template DNA was omitted (not shown). Analysis of region A showed that most of the agrin mRNA from non-neural tissues had no insert in this position $\left(A_{0}\right)$, while agrin mRNA from the embryonic neural tissues consisted largely of molecules coding for the four amino acid insert $\left(\mathrm{A}_{4}\right.$, Fig. $\left.7 A\right)$. A small amount of $\mathrm{A}_{4}$ was also seen in PCR products from nonneural tissues, but only after longer exposures of autoradiograms. Amplification of region B yielded PCR products (95$152 \mathrm{bp}$ ) lacking the $B$ insert $\left(B_{0}\right)$ in non-neural tissues, while the nervous system contained both $B_{0}$ and sequences coding for 11 amino acid $\left(\mathrm{B}_{11}\right)$ and 19 -amino acid $\left(\mathrm{B}_{19}\right)$ inserts (Fig. $7 B$ ). No $B_{8}$ insert was seen at these stages, but a band of this size was seen in reactions from E14-E20 spinal cord (not shown). The size of the PCR products was estimated by electrophoresis of unlabeled products from similar reactions with DNA size standards on ayarose gels stained with ethidium bromide (not shown). To confirm that the amplified PCR products represented agrin mRNA variants, the $B$ region bands were sequenced directly. Sequence analysis confirmed that the bands were amplified from agrin cDNA. The $B_{0}$ and $B_{11}$ sequences were identical to the agrin mRNA variants identified by Ruegg et al. (1992); the $B_{19}$ sequence coded for the 11 -amino acid insert in tandem with an 8 -amino acid insert (Fig. $7 C$ ). Six of the eight amino acids were identical to those in the corresponding rat insert (Ferns et al., 1992). Amino acid sequences of the chicken agrin inserts were recently published (Thomas et al., 1993); here we present the DNA sequences as well. Sequencing showed that one nucleotide, immediately to the 5 ' side of the inserts (underlined, Fig. $7 \mathrm{C}$ ), was different from the previously published sequence (Ruegg et al., 1992; Tsim et al., 1992).

\section{Discussion}

We have shown that agrin mRNAs in the chick embryo nervous system are concentrated in (1) neurons that send long projections through nerves, that is, motor, sensory, and retinal ganglion neurons; (2) a relatively small number of neuronal layers and nuclei in the brain, including those in optic tectum and cerebellum; and (3) ventricular layers throughout the developing nervous system. Most of the neurons that appear to have a higher agrin mRNA content fall into pairs with their target cells, which also express an elevated level of agrin mRNAs, namely, motor neurons and muscle cells, sensory and motor neurons, retinal ganglion and tectal neurons, and cerebellar Purkinje and granule cells. There is also a low level of agrin mRNA expression throughout the nervous system. Non-neural tissues appear to contain only agrin mRNA lacking a B insert, which encodes proteins with little or no AChR-aggregating activity, based on expression of partial cDNAs in transfected cells (Ruegg et al., 1992). However, all regions of the embryonic chick nervous system contain at least three agrin mRNA variants, due to alternative splicing at sequence position $B$. While the biological functions of the proteins encoded by these isoforms have not been fully investigated, these results raise the intriguing possibility that different agrin isoforms have different functions in ncrvous systcm devclopment. For example, some agrin isoforms may play a role in the organization of neuron-neuron synapses.

In the developing spinal cord, beginning at E4 (St 23), presumptive motor neurons had a higher agrin mRNA content than surrounding cells. At this stage, motor axons have already exited the spinal cord, but have not yet entered the limb (Tosney and Landmesser, 1985). Our preliminary results (E. Ma and E. W. Godfrey, unpublished observations) indicate that agrin mRNAs coding for the 11- and 19-amino acid inserts at position B first appear at about this stage. Thus, prior to synaptogenesis with muscle cells in the hindlimb at and after St 26 (Landmesser and Morris, 1975), the motor neurons acquire machinery for alternative splicing that produces mRNA encoding agrin isoforms capable of organizing the postsynaptic apparatus. These results suggest that active agrin may be externalized by motor axons before they enter muscle masses. This notion is consistent with results of two recent studies. First, Dahm and Landmesser (1991) showed that AChRs were clustered in early limb muscle masses soon after muscle nerves entered them, even prior to branching. Thus, AChR clusters were seen up to $200 \mu \mathrm{m}$ from the nerve, suggesting that in the chick embryo the nerve secretes a diffusible factor capable of inducing these structures prior to axon-muscle cell contact. Second, Cohen and Godfrey (1992) found that axons of embryonic frog spinal cord neurons in culture externalize and display on their surfaces microclusters of neuronally derived agrin, even in regions of the culture where the axons did not contact muscle cells. Over $90 \%$ of the AChR microclusters induced by these axons on muscle cells were colocalized with agrin microclusters, suggesting that the latter contain biologically active molecules. Further, frog spinal cord neurons in culture externalize active agrin molecules in the absence of muscle cells (Cohen et al., 1994). Thus, just as motor axons secrete $\mathrm{ACh}$ prior to contact with muscle cells (Young and Poo, 1983), motor neurons appear to have active mechanisms for translation, transcription, and externalization of active agrin isoforms prior to synaptogenesis.

Dorsal root ganglia had an intense agrin mRNA signal from E4 until at least EI4. The signal was most intense in the largest cells, presumably neurons. This localization is puzzling, because our data indicate that the same agrin mRNA variants are present in sensory ganglia as in spinal cord, yet sensory neurons do not cause aggregation of AChRs on muscle cells (Cohen et al., 1979; Role et al., 1985). Perhaps there is a difference in the synthesis, transport, or externalization of agrin molecules in sensory neurons as compared to motor neurons.

Agrin mRNAs were also concentrated in ventricular germinal zones of the spinal cord and the brain. In the spinal cord, the hybridization signal near the central canal was first apparent at E4, but became very intense and extensive at E5-E6, especially in the dorsal half of the spinal cord. At later stages this signal gradually decreased, disappearing completely after E14. We had previously observed fibrils of agrin immunofluorescence radiating from the dorsal end of the central canal of E5-E12 chick embryo spinal cord (R. E. Siebenlist and E. W. Godfrey, unpublished observations). Others have observed agrin immu- 

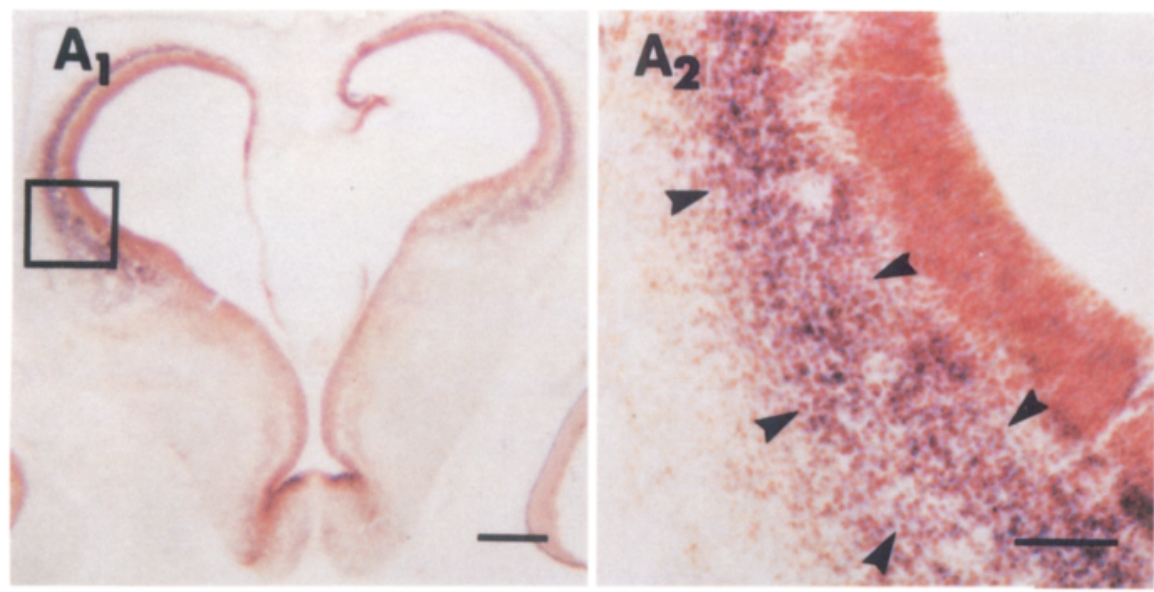

$A_{3}$

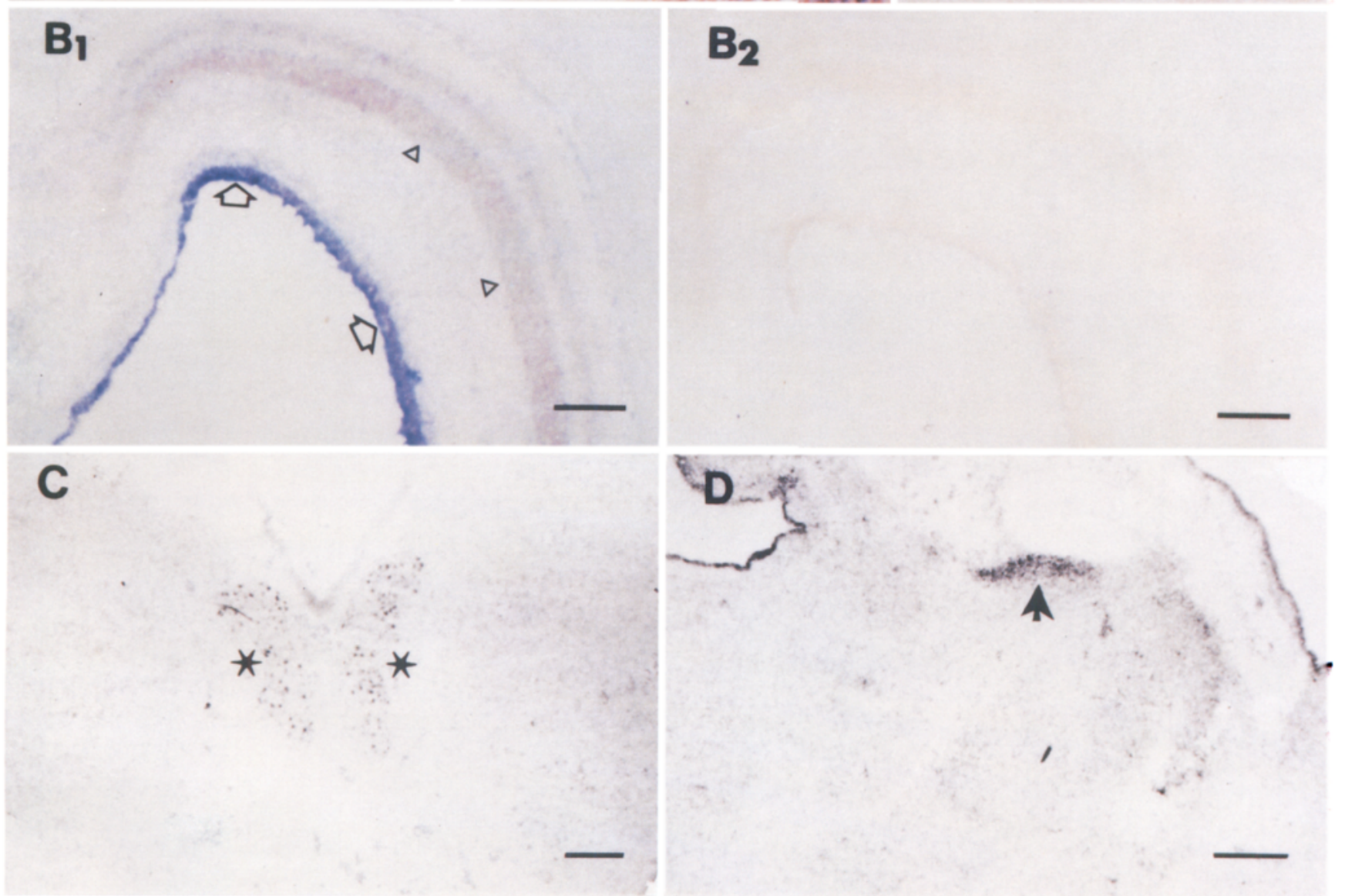

Figure 5. Distribution of agrin mRNAs in developing chick embryo brain. $A_{1}$, E6 (St 28) telencephalon, coronal section. $A_{2}$, an enlargement of superior region (boxed area) in $A_{l}$. The signal was most concentrated in the region surrounded by arrowheads. $A_{3}$, Sense cRNA control for $A_{2}$. $B_{l}$, E10 (St 36) optic tectum, coronal section; signal is in ventricular layer (arrows) and presumptive neuronal layers (arrowheads). $B_{2}$, Sense cRNA control for $B_{l}$. C, E14 (St 40) medulla, showing signal in cranial motor neurons (asterisks). D, E9 (St 35) diencephalon, sagittal section, showing habenular nucleus (arrow). $A$ and $B$ in color; $C$ and $D$ in black and white. Scale bars: $A_{l}, B_{l}, B_{2}, C$, and $D, 300 \mu \mathrm{m} ; A_{2}$ and $A_{3}, 100 \mu \mathrm{m}$.

nofluorescence and/or in situ hybridization signal near the central canal of chick (Tsim et al., 1992) and rat embryo spinal cord (Rupp et al., 1991). The function of agrin in the ventricular zone is unlikely to be related to synaptogenesis, because ventricular cells divide to create new neurons and glial cells. The agrin mRNA in this region does not contain any of the B inserts, because in situ hybridization with antisense oligonucleotides specific for either $B_{8}$ or $B_{11}$ sequences does not give a signal in the ventricular zone, as it does in the ventrolateral region (Ma and Godfrey, unpublished observations). The temporal pattern of agrin mRNA expression correlates with the period of rapid cell division in the dorsal germinal zone of the spinal cord (Hamburger, 1948), so agrin may play a role in cell division and/or migration in this structure. An intense signal for agrin mRNA was also seen in ventricular zones in the brain and, interestingly, in a zone subjacent to the germinal layer in the telencephalon at E6 but not at E9. Although birds do not have a true cerebral cortex, this layer may be related to the transient cortical subplate neurons that are generated early in the development of mammalian cortex (Luskin and Shatz, 1985). 

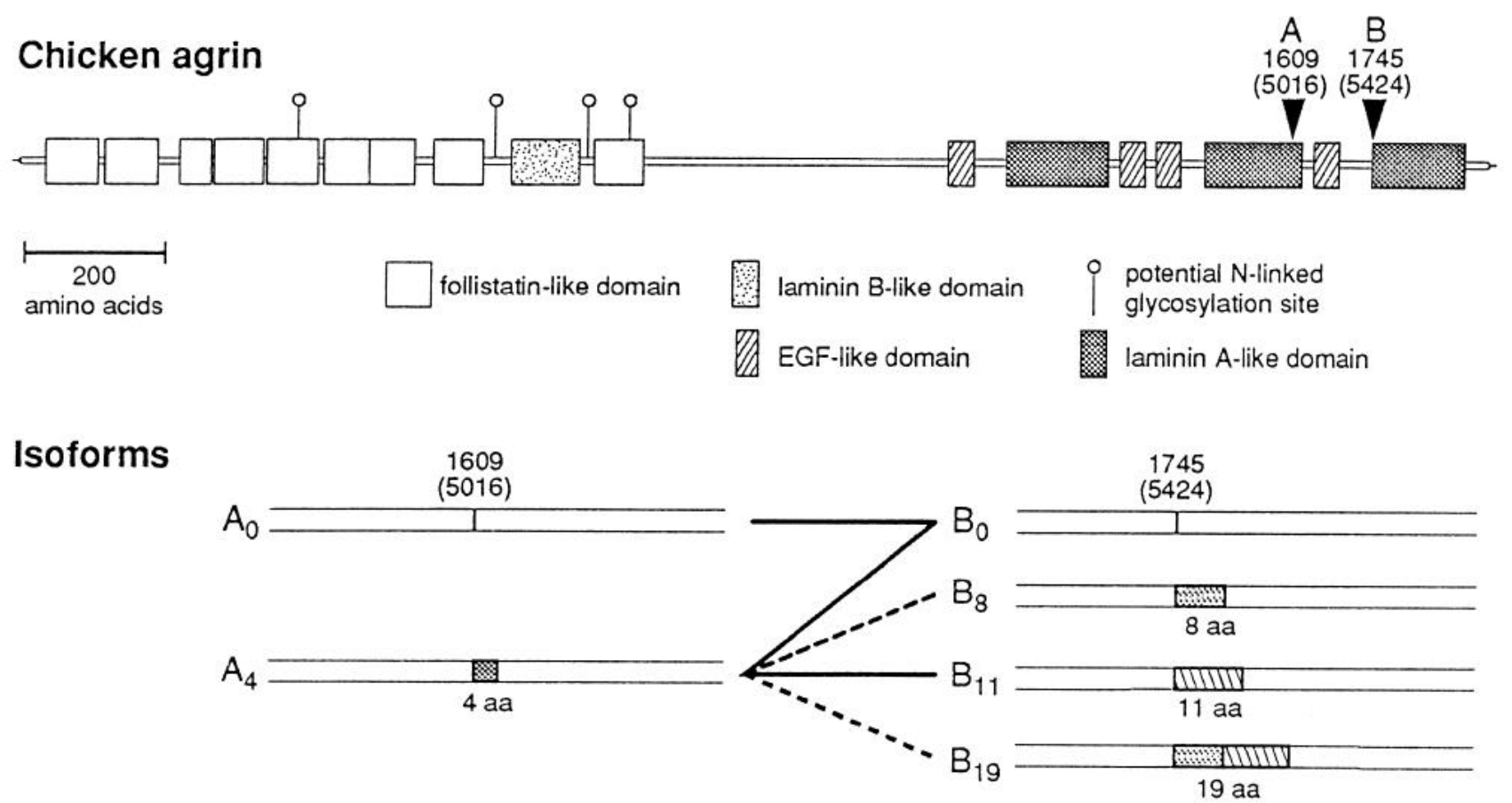

Figure 6. Diagram of chicken agrin cDNA structure (modified from McMahan et al., 1992) and position of variant sequences in regions $A$ and $B$ [numbers under $A$ and $B$ represent amino acid and base numbers from agrin sequence reported by Tsim et al. (1992)]. The combinations $A_{0} B_{0}$, $A_{4} B_{0}$, and $A_{4} B_{11}$ (linked with solid lines) are variants identified by Tsim et al. (1992) and Ruegg et al. (1992). Dashed lines indicate probable $A_{4} B_{8}$ and $A_{4} B_{19}$ variants, which have been formally demonstrated in rat (Hoch et al., 1993) but not in chick.

A

\section{2}

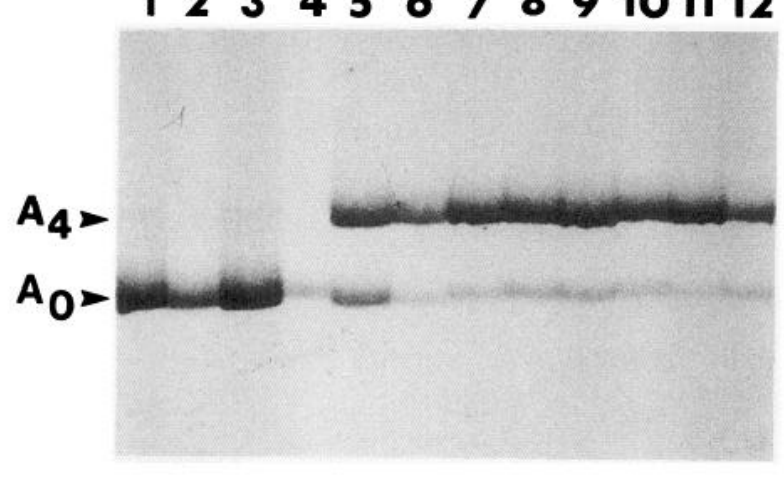

B

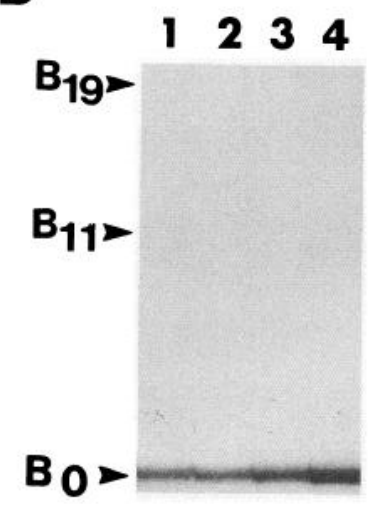

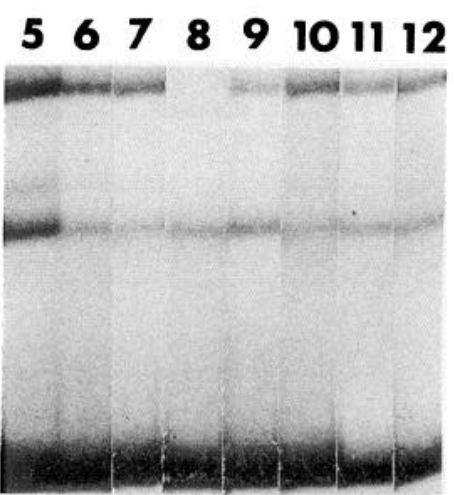

C $\operatorname{chick} B_{0}:$
$\operatorname{chick} B_{11}$
$\operatorname{chick} B_{19}$
rat $B_{19}:$

5419

(1744)

AAGA

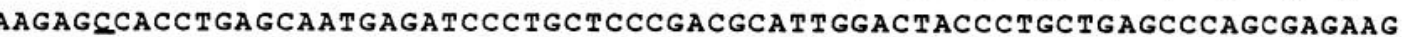

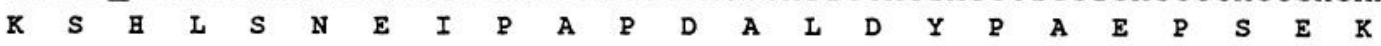

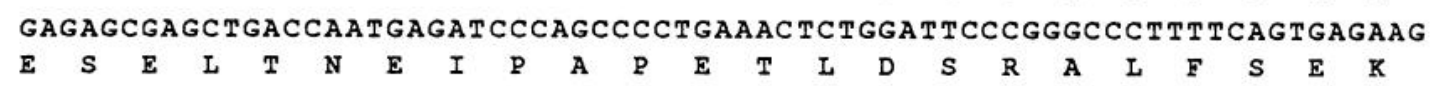

Figure 7. Analysis of agrin mRNA sequence variants in chick embryo tissues by PCR. Two variable regions were amplified from cDNA prepared from E10 chick embryo tissues (except E6 heart and E4 limb bud), as described in Materials and Methods. A, Region A (see Fig. 6) PCR products; $A_{s}$, variant containing a 12 bp (4 amino acid) insert; $A_{0}$, variant without the insert. $B$, Region B PCR products; $B_{I g}$, variant containing insert coding for a 19 amino acid insert; $B_{11}, 11$ amino acid insert; $B_{0}$, no insert. Lanes in $A$ and $B: 1$, limb bud; 2 , muscle; 3 , kidney; 4 , heart; 5 , dorsal root 
The distribution of agrin mRNAs in the developing brain raises some interesting questions about the possible function of the agrin isoforms they encode. Apart from the intense agrin mRNA signal in ventricular regions at early stages, the sites with the greatest hybridization included retinal ganglion cells, cranial motor nuclei, habenular nuclei, layers in the optic tectum, and cerebellar Purkinje cells. It is remarkable that an intense agrin mRNA signal is found in so few structures in the developing brain, although a low level of specific hybridization was seen throughout the nervous system. The limited number of structures expressing a high level of agrin mRNA suggests that the agrin isoform(s) made by neurons in these structures has a specific function(s) unique to these cells. The most obvious possibility is that agrin organizes postsynaptic components, including neurotransmitter receptors, at the synapses made by these neurons. Another possible function could be in neuronncuron adhesion and recognition prior to synaptogenesis. Yet a third possibility is that at least some agrin isoforms are externalized by axons to function in neurite outgrowth. Preliminary evidence shows that agrin binds to laminin and other basal lamina components (Godfrey, 1991; N. Drzewiecki and E. W. Godfrey, unpublished observations). Perhaps agrin, especially isoforms lacking an insert at position $\mathrm{B}$, which may have low AChR-aggregating activity (Godfrey, 1991; Ferns et al., 1992, 1993; Tsim et al., 1992), is externalized by axons, binds to laminin or other ECM molecules, and enhances neurite outgrowth. This is an especially attractive hypothesis to account for the large amount of agrin mRNAs in sensory ganglia and retinal ganglion cells. Both sensory ganglia and retina seem to contain mostly $A_{4} B_{0}$ mRNA. It remains to be determined whether neurons in these structures contain this form, or if it is only found in non-neuronal cells. Although this mRNA form is present in spinal cord, it does not seem to be enriched in motor neurons (Tsim et al., 1992). The low level of specific hybridization seen throughout the developing nervous system suggests that agrin mRNA is made by non-neuronal cells as well as neurons. This has already been demonstrated in the optic and sciatic nerves of chick embryos (Ruegg et al., 1992). Levels of expression in non-neuronal cells may be low, but agrin made by these cells could also have important functions, for example, in cell adhesion or neurite outgrowth.

In the embryonic nervous system, we found that most agrin mRNA contained the sequence coding for the 4-amino acid insert at position A, as previously shown by Ruegg et al. (1992). However, we observed three variants at the $B$ position in this study. In addition to the $B_{0}$ sequence (coding for a protein without an insert), there were agrin mRNA molecules containing sequence $\mathrm{B}_{11}$, coding for an 11 -amino acid insert (Ruegg et al., 1992; Tsim et al., 1992) and $B_{19}$ (for a 19-amino acid insert; Thomas et al., 1993) throughout the embryonic nervous system. Agrin mRNAs containing a $\mathrm{B}_{8}$ insert have also been demonstrated in ciliary ganglia (Thomas et al., 1993), spinal cord, and dorsal root ganglia of older chick embryos (Ma and Godfrey, unpublished observations). Thus, there are four variants at the
B position in the chicken agrin scquencc, corresponding to the variants observed in the rat agrin sequence at this position (Ferns et al., 1992). It will be interesting, though difficult, to determine the function of the agrin isoforms in CNS development. New assays and approaches will be required to address this question.

\section{References}

Angerer LM, Stoler MH, Angerer RC (1987) In sttu hybridization with RNA probes: an annotated recipe. In: In situ hybridization: applications to neurobiology (Valentino $\mathrm{KL}$, Eberwine JH, Barchas JD, eds), pp 42-70. New York: Oxford UP.

Cohen MW, Godfrey EW (1992) Early appearance of and neuronal contribution to agrin-like molecules at embryonic frog nerve-muscle synapses formed in culture. J Neurosci 12:2982-2992.

Cohen MW, Anderson MJ, Zorychta E, Weldon PR (1979) Accumulation of acetylcholine receptors at nerve-muscle contacts in culture. Prog Brain Res 49:335-349.

Cohen MW, Moody-Corbett F, Godfrey EW (1994) Neuritic deposition of agrin on culture substrate: implications for nerve-muscle synaptogenesis. J Neurosci, in press.

Dahm LM, Landmesser LT (1991) The regulation of synaptogenesis during normal development and following activity blockade. J Neurosci 11:238-255.

Ferns M, Hoch W, Campanelli JT, Rupp R, Hall ZW, Scheller RH (1992) RNA splicing regulates agrin-mediated acetylcholine receptor clustering activity on cultured myotubes. Neuron 8:1079-1086.

Ferns M J, Campanelli JT, Hoch W, Scheller RH, Hall Z (1993) The ability of agrin to cluster AChRs depends on alternative splicing and on cell surface proteoglycans. Neuron 11:491-502.

Godfrey EW (1991) Comparison of agrin-like proteins from the extracellular matrix of chicken kidney and muscle with neural agrin, a synapse organizing protein. Exp Cell Res 195:99-109.

Godfrey EW, Nitkin RM, Wallace BG, Rubin LL, McMahan UJ (1984) Components of Torpedo electric organ and muscle that cause aggregation of acetylcholine receptors on cultured muscle cells. J Cell Biol 99:615-627.

Godfrey EW, Dietz ME, Morstad AL, Wallskog PA, Yorde DE (1988a) Acetylcholine receptor-aggregating proteins are associated with the extracellular matrix of many tissues in Torpedo. J Cell Biol 106:12631272.

Godfrey EW, Siebenlist RE, Wallskog PA, Walters IM, Bolender DL, Yorde DE (1988b) Basal lamina components are concentrated in premuscle masses and at early acetylcholine receptor clusters in chick embryo hindlimb muscles. Dev Biol 130:471-486.

Hamburger V (1948) The mitotic patterns in the spinal cord of the chick embryo and their relation to histogenetic processes. J Comp Neurol 88:221-284.

Hamburger V, Hamilton HL (1951) A series of normal stages in the development of chick embryo. J Morphol 88:49-92.

Hoch W, Ferns M, Campanelli JT, Hall ZW, Scheller RH (1993) Developmental regulation of highly active alternatively spliced forms of agrin. Neuron 11:479-490.

Landmesser L, Morris DG (1975) The development of functional innervation in the hind limb of the chick embryo. J Physiol (Lond) 249:301-326.

Luskin MB, Shatz CJ (1985) Studies of the earliest generated cells of the cat's visual cortex: cogeneration of subplate and marginal zones. J Ncurosci 5:1062-1075.

Ma E, Godfrey EW (1992) Distribution of agrin mRNAs in the developing chick embryo. Soc Neurosci Abstr 18:207.

Magill-Solc C, McMahan UJ (1988) Molor neurons contain agrin-like molecules. J Cell Biol 107:1825-1833.

Magill-Solc C, McMahan UJ (1990) Synthesis and transport of agrinlike molecules in motor neurons. J Exp Biol 153:1-10.

ganglion; 6 , spinal cord; 7 , telencephalon; 8 , diencephalon; 9 , brainstem; 10 , optic tectum; 11 , retina; 12 , cerebellum. All lanes represent products of one round of amplification, except for lane 11 (retina) in $B$, which shows products of a reamplification. No PCR products were observed in these size ranges when cDNA template was omitted. $C$, DNA sequence of variants in region B. The PCR products were separated, purified, and sequenced directly, as described in Materials and Methods. Both nuclentide and deduced amino acid sequences are presented. The underlined nucleotide $C$ was previously reported as T (Tsim et al., 1992). For comparison, the DNA and deduced protein sequences of the 19 amino acid insert of rat agrin are also shown (Rupp et al., 1992). 
McMahan UJ, Horton SE, Werle MJ, Honig LS, Kröger S, Rucgg MA, Escher G (1992) Agrin isoforms and their role in synaptogenesis. Curr Opin Cell Biol 4:869-874.

Nitkin RM, Smith MA, Magill C, Fallon JR, Yao Y-MM, Wallace BG, McMahan UJ (1987) Identification of agrin, a synaptic organizing protein from Torpedo electric organ. J Cell Biol 105:2471-2478.

Rager G (1976) Morphogenesis and physiogenesis of the retino-tectal connection in the chicken. II. The retino-tectal synapse. Proc R Soc Lond [Biol] 192:353-370.

Reist NE, Magill C, McMahan UJ (1987) Agrin-like molecules at synaptic sites in normal, degenerated, and damaged skeletal muscle. J Cell Biol 105:2457-2469.

Reist NE, Werle MJ, McMahan UJ (1992) Agrin released by motor neurons induces the aggregation of acetylcholine receptors at neuromuscular junctions. Ncuron 8:865-868.

Role LW, Matossian RR, O'Brien RJ, Fischbach GD (1985) On the mechanism of acetylcholine receptor accumulation at newly formed synapses of chick myotubes. J Neurosci 5:2197-2204.

Ruegg MA, Tsim KWK, Horton SE, Kröger S, Escher G, Gensch EM, McMahan UJ (1992) The agrin gene codes for a family of basal lamina proteins that differ in function and distribution. Neuron 8:120.
Rupp F, Payan DG, Magill-Solc C, Cowan DM, Scheller RH (1991) Structure and expression of a rat agrin. Neuron 6:811-823.

Rupp F, Ozcelik TH, Linial M, Petterson K, Francke U, Scheller RH (1992) Structure and chromosomal localization of the mammalian agrin gene. J Neurosci 12:3535-3544.

Sambrook J, Fritsch EF, Maniatis T (1989) Molecular cloning-a laboratory manual, 2d ed. Cold Spring Harbor, NY: Cold Spring Harbor Laboratory.

Thomas WS, O'Dowd DK, Smith MA (1993) Developmental expression and alternative splicing of chick agrin RNA. Dev Biol 158: 523-535.

Tosney, KW, Landmesser, LT (1985) Development of the major pathways for neurite outgrowth in the chick hindlimb. Dev Biol 109:193214

Tsim KWK, Ruegg MA, Escher G, Kröger S, McMahan UJ (1992) cDNA that encodes active agrin. Neuron 8:677-689.

Wallace, BG (1989) Agrin-induced specializations contain cytoplasmic, membrane, and extracellular matrix-associated components of the postsynaptic apparatus. J Neurosci 9:1294-1302.

Young SH, Poo M-M (1983) Spontaneous release of acetylcholine from growth cones of embryonic neurons. Nature 305:634-637. 